\title{
The Influence of Sulfuric Acid Catalyst Concentration on Hydrolysis of Birch Wood Hemicelluloses
}

\author{
Olga V. Yatsenkova ${ }^{a}$, \\ Anna I. Chudina ${ }^{a}$, Andrey M. Skripnikova, \\ Nikolay V. Chesnokov ${ }^{\text {a, }}$ b and Boris N. Kuznetsov*a, b \\ anstitute of Chemistry and Chemical Technology SB RAS \\ 50-24 Akademgorodok, Krasnoyarsk, 660036, Russia \\ ${ }^{b}$ Siberian Federal University \\ 79 Svobodny, Krasnoyarsk, 660041, Russia
}

Received 13.03.2015, received in revised form 23.04.2015, accepted 19.05.2015

The influence of sulfuric acid catalyst concentration on hydrolysis of birch wood hemicelluloses under mild conditions (temperature of $100^{\circ} \mathrm{C}$ and atmospheric pressure) was studied. It was found that the maximum yield of xylose $(72,4-77,1 \% \mathrm{wt}$. of the initial content of hemicelluloses in birch) is achieved at a concentration of $\mathrm{H}_{2} \mathrm{SO}_{4} 2-3 \%$ by weight and hydrolysis process duration of 5 hours. According to gas chromatographic analysis the obtained hydrolysates contain mainly xylose, and at minor amounts mannose and glucose. The solid products of birch wood hydrolysis contain cellulose (56,8-70,4\% wt.), lignin $(19,8-28,8 \% w t$.) and hemicelluloses $(2,8-15,3 \% w t$.). They have a higher crystallinity index compared to initial birch wood.

Keywords: birch-wood, hydrolysis, sulfuric acid catalyst, hemicelluloses, xylose.

DOI: $10.17516 / 1998-2836-2015-8-2-211-221$.

(C) Siberian Federal University. All rights reserved

* Corresponding author E-mail address: inm@icct.ru 


\title{
Влияние концентрации сернокислотного катализатора на гидролиз гемицеллюлоз древесины березы
}

\author{
О.В. Яценкова ${ }^{a}$, А.И. Чудина ${ }^{\mathrm{a}}$, А.М. Скрипников ${ }^{\mathrm{a}}$, \\ Н.В. Чесноков ${ }^{\text {a, },}$, Б.Н. Кузнецов ${ }^{\text {a, }}$ \\ ${ }^{a}$ Институт химии и химической технологии СО РАН \\ Россия, 660036, Красноярск, Академгородок, 50/24 \\ ${ }^{6}$ Сибирский федеральный университет \\ Россия, 660041, Красноярск, пр. Свободныий, 79
}

Изучено влияние концентрации сернокислотного катализатора на гидролиз гемицеллюлоз древесины березы в мягких условиях (температура $100{ }^{\circ} \mathrm{C}$ и атмосферное давление). Установлено, что максимальный выход ксилозы (72,4-77,1% мас. от исходного содержания гемицеллюлоз в березе) достигается при концентрации $\mathrm{H}_{2} \mathrm{SO}_{4}$ 2-3 \% мас. и продолжительности процесса гидролиза 5 ч. Газохроматографический анализ полученных гидролизатов показал, что они преимущественно содержат ксилозу и незначительные количества маннозы и глюкозы. Твердые продукты гидролиза древесины березы содержат иеллюлозу (56,8-70,4 \% мас.), лигнин (19,8-28,8 \% мас.) и гемицеллюлозы (2,8-15,3\% мас.). Они имеют более высокий индекс кристалличности, чем исходная древесина березы.

Ключевые слова: древесина березы, сернокислотный катализатор, гидролиз, гемицеллюлозы, ксилоза.

\section{Введение}

Процессы кислотно-каталитической деполимеризации гемицеллюлоз (ГЦ) используют для получения ксилозы и других ценных продуктов на ее основе, а также для удаления гемицеллюлоз с целью повышения эффективности процессов получения из лигноцеллюлозного сырья качественных глюкозных гидролизатов и реализации комплексной переработки основных компонентов биомассы в востребованные химические продукты [1-4].

Ксилозу преимущественно получают кислотно-каталитическим гидролизом гемицеллюлоз растительного сырья. Среди древесных пород, произрастающих в России, наиболее высокое содержание гемицеллюлоз (до 30 \% мас.) имеет древесина березы.

Наличие большого количества гемицеллюлоз и высокая плотность древесины березы затрудняет применение традиционных технологий для ее переработки в целлюлозу и глюкозные гидролизаты для синтеза биоспиртов. С учетом наличия в древесине березы значительных количеств пентозанов экономически целесообразно осуществлять ее комплексную переработку с предварительным выделением ксилозы в качестве одного из целевых продуктов.

В работе [5] осуществлен подбор условий кислотного гидролиза древесины березы, обеспечивающих максимальное извлечение пентозанов. Исследования показали, что гидролиз древесины березы при температуре $60{ }^{\circ} \mathrm{C}$ в течение 2-3 ч не позволяет достичь высокой степени извлечения пентозанов (8-10 \% от массы а.с.д.) даже при концентрации серной кислоты 
в растворе $20 \%$. Повышение концентрации кислоты до $32 \%$ увеличивает выход пентозанов до 20-25 \% за такую же продолжительность гидролиза. Аналогичный эффект достигается с ростом температуры гидролиза до $98^{\circ} \mathrm{C}$ при концентрации серной кислоты $3 \%$ мас. и продолжительности процесса 2-3 ч.

В работе [6] при получении гидролизатов из древесины березы сначала проводили водную экстракцию древесины в автоклаве при $165{ }^{\circ} \mathrm{C}$, а затем гидролиз $72 \% \mathrm{H}_{2} \mathrm{SO}_{4}$ при $25^{\circ} \mathrm{C}$ в течение 2 ч. После этого смесь разбавляли водой до концентрации $40 \% \mathrm{H}_{2} \mathrm{SO}_{4}$ и проводили инверсию олигосахаридов при 60 и $80{ }^{\circ} \mathrm{C}$ в течение 10 и 60 мин. При этом конверсия древесины достигала 23,7-27,4 \% мас. В составе растворимых продуктов идентифицировано около 4 \% лигнина, $3 \%$ уроновых кислот и 11,3-20,0 \% растворенных моносахаров, из которых 15,5 \% составляет ксилоза.

Полное извлечение ксилозы в процессе обработки березовой древесины перегретым паром при температурах $180-240{ }^{\circ} \mathrm{C}$ достигнуто за счет потери около $15 \%$ мас. в выходе целлюлозы [7]. Помимо ксилоолигосахаридов и мономеров ксилозы в водном экстракте обнаружено существенное количество фурфурола и уксусной кислоты.

При обработке древесины березы, пропитанной раствором 0,14 \% мас. $\mathrm{H}_{2} \mathrm{SO}_{4}$, водяным паром при $200{ }^{\circ} \mathrm{C}$ в течение 5 мин в условиях взрывного автогидролиза гемицеллюлозы в основном гидролизуются до водорастворимых продуктов, а лигнин остается в твердой фракции сырья [8]. При обработке автогидролизованной древесины $0,25 \mathrm{M} \mathrm{Na}_{2} \mathrm{CO}_{3}$ при $120{ }^{\circ} \mathrm{C}$ в течение 20 ч большая часть лигнина переходит в растворимое состояние, а гемицеллюлозы остаются в твердой фракции $[8,9]$.

Предложенный метод [10] извлечения ксилозы из древесины березы предполагает гидролиз березовой щепы $0,01 \mathrm{M} \mathrm{раствором} \mathrm{уксусной} \mathrm{кислоты} \mathrm{при} 140{ }^{\circ} \mathrm{C}$ в течение 1 ч и последующую экстрацию гемицеллюлоз $1 \mathrm{M} \mathrm{NaOH}$ в течение 16 ч. Полученная фракция представляет собой смесь ксилозы и лигнина и нуждается в сложной последовательной очистке и осаждении лигнина из раствора сахаров.

Осуществление предгидролиза древесины, разбавленной серной или другими кислотами, при повышенных температурах обеспечивает достаточно высокий выход сахаров [11], причем экономически целесообразно применение разбавленной серной кислоты [12].

Необходимо отметить, что определенную часть гемицеллюлоз очень трудно удалить из древесины путем гидролиза. В целлюлозе всегда остаются остаточные гемицеллюлозы, сокристаллизованные с целлюлозой, которые являются трудногидролизуемыми [13].

Таким образом, кислотно-каталитический гидролиз древесины дает набор $\mathrm{C}_{5}$ и $\mathrm{C}_{6}$ сахаров и различных водорастворимых соединений, образующихся при деполимеризации гемицеллюлоз, аморфной части целлюлозы, реакционноспособной части лигнина, а также вследствие вторичных превращений продуктов гидролиза [14].

Для обеспечения селективной деполимеризации ГЦ необходимо подобрать оптимальные условия гидролитической конверсии древесины (температура, состав реакционной среды и т.п.), при которых к минимуму сводятся превращения других древесных компонентов.

Цель настоящей работы - подбор условий реакции гидролиза древесины березы разбавленной серной кислотой для максимального извлечения ксилозы в мягких условиях (при атмосферном давлении и температуре $\left.100^{\circ} \mathrm{C}\right)$.

$$
-213-
$$




\section{Экспериментальная часть}

\section{Исходное сырье}

В экспериментах использовали воздушно-сухие опилки древесины березы, произрастающей в окрестностях г. Красноярска (фракция 2-5 мм). Состав древесины березы, определенный по стандартным методикам [15] ( \% от массы абсолютно сухой древесины): целлюлоза - 46,8; лигнин - 21,7; гемицеллюлозы - 27,3; экстрактивные вещества - 3,2.

\section{Гидролиз древесины березы}

Навеску воздушно-сухой древесины березы в количестве 10 г помещали в трехгорлую круглодонную колбу из термостойкого стекла объемом 500 мл, снабженную мешалкой, обратным холодильником и термометром. Затем приливали 80 мл водного раствора $1-4 \%$ мас. $\mathrm{H}_{2} \mathrm{SO}_{4}$ (х.ч., ГОСТ 4204-77). Гидролиз проводили при атмосферном давлении, температуре $100{ }^{\circ} \mathrm{C}$, в течение 1-5 ч, при интенсивности перемешивания 14 об/с. По истечении заданного времени полученный гидролизат остужали до комнатной температуры, отфильтровывали на воронке Бюхнера на бумажном фильтре под вакуумом, переливали в бюкс, закрывали притертой крышкой и анализировали на газовом хроматографе «VARIAN-450». Негидролизованный древесный остаток промывали дистиллированной водой до нейтральной реакции промывных вод и высушивали в сушильном шкафу при температуре $103{ }^{\circ} \mathrm{C}$. Конверсию древесины определяли весовым методом с точностью $\pm 2-3 \%$.

\section{Анализ гидролизатов}

Индивидуальный состав и содержание моносахаров в гидролизатах определяли хроматографическим методом с применением газового хроматографа «VARIAN-450 GC» с пламенноионизационном детектором. Использовали капиллярную колонку VF-624ms длиной 30 м, внутренним диаметром 0,32 мм. Условия хроматографирования: газ-носитель - гелий; температура инжектора $250{ }^{\circ} \mathrm{C}$; начальная температура термостата колонки $50{ }^{\circ} \mathrm{C}$ (5 мин), подъем температуры до $180{ }^{\circ} \mathrm{C}$ со скоростью $10{ }^{\circ} \mathrm{C} /$ мин, выдержка при $180{ }^{\circ} \mathrm{C} 37$ мин. Температура детектора $280{ }^{\circ} \mathrm{C}$. Продолжительность хроматографического разделения моносахаридов составляла 55 мин. Для регистрации выхода олигосахаридов после 55 мин анализа температуру термостата поднимали до $250{ }^{\circ} \mathrm{C}\left(10^{\circ} \mathrm{C} /\right.$ мин $)$ и выдерживали колонку при данной температуре 30 мин. Общее время анализа при этом составляло 92 мин.

Пробу гидролизата предварительно подвергали дериватизации по методике [16] с образованием триметилсилильных производных. Для этого в круглодонную колбу емкостью $15 \mathrm{~cm}^{3}$ вносили пробу нейтрализованного гидролизата, содержащего около 10 мг сахаров и 4 мг сорбита (раствор сорбита готовили ранее). Раствор упаривали досуха при температуре $40-42{ }^{\circ} \mathrm{C}$. Для удаления следов воды к упаренной пробе дважды добавляли по 1 мл спиртотолуольной смеси (4:1), которую также удаляли упариванием. К сухому остатку прибавляли 1 мл свежеперегнанного сухого пиридина. Если анализируемая проба плохо растворялась, колбу нагревали на водяной бане при температуре $75-85{ }^{\circ} \mathrm{C}$ в течение 2-3 мин. Для установления устойчивого равновесия между таутомерными формами моносахаридов раствор пробы упаренного гидролизата в пиридине выдерживали в течение 12-20 ч. Затем к раствору добавляли 0,3 мл гексаметилдисилазана и 0,15 мл триметилхлорсилана. Колбу закрывали пробкой, энергично 
встряхивали 30 с и при комнатной температуре выдерживали реакционную смесь в течение 10 мин. При добавлении триметилхлорсилана раствор мутнел из-за выпадения в осадок хлористого аммония. Пиридин упаривали из реакционной смеси при помощи водоструйного насоса при температуре $40{ }^{\circ} \mathrm{C}$. Затем в колбу вносили 1 мл н-гексана, отфильтровывали полученный раствор через конусообразную стеклянную воронку с бумажным фильтром и подвергали хроматографированию.

Полученная хроматограмма включает пики всех содержащихся в пробе гидролизата таутомеров моносахаридов. Идентификацию пиков проводили, пользуясь ранее установленными для данных условий хроматографирования значениями времен удерживания таутомерных форм моносахаридов [16]. Рассчитывали отношение суммы площадей характеристических пиков моносахарида к площади пика внутреннего стандарта (Si/Sct). По этим соотношениям с помощью градуировочного графика находили массу каждого моносахарида в пробе гидролизата (градуировочные графики для эталонных растворов моносахаридов строили ранее). В качестве стандартов для анализа использовали следующие моносахара: глюкоза кристаллическая гидратная (ГОСТ 975-88), D-ксилоза 142080.1208 (Panreac), D-манноза 373195,1208 (Panreac), D-сорбит (Panreac).

\section{Анализ гидролизованной древесинь}

В твердых остатках гидролизованных образцов древесины березы определяли содержание легкогидролизуемых полисахаридов, трудногидролизуемых полисахаридов и лигнина Класона (в модификации Комарова) по стандартным методикам [15].

Рентгенограммы образцов древесины получали с применением дифрактометра «Дрон-3М» с излучением $\mathrm{CuK} \alpha(\lambda=0,154$ нм). Съемку дифрактограмм осуществляли в интервале углов $2 \theta$ от 5 до $70^{\circ}$ с шагом $0,01^{\circ}$. Индекс кристалличности целлюлозы рассчитывали в соответствии с методикой, описанной в работе [17].

\section{Результаты и обсуждения}

Для подбора оптимальных условий гидролиза древесины березы, обеспечивающих максимальный выход ксилозы, варьировали концентрацию сернокислотного катализатора от 1 до $4 \%$ мас. и продолжительность процесса от 1 до 5 ч при температуре $100{ }^{\circ} \mathrm{C}$, гидромодуле 8 и атмосферном давлении. Обнаружено, что степень конверсии древесины повышается при увеличении концентрации сернокислотного катализатора и продолжительности гидролиза, а содержание остаточных гемицеллюлоз снижается с 27,3 \% мас. в исходной древесине до $2,8 \%$ мас. в лигноцеллюлозе, полученной гидролизом древесины $4 \% \mathrm{H}_{2} \mathrm{SO}_{4}$ в течение 5 ч (табл. 1).

Химический анализ лигноцеллюлозного продукта показал, что минимальное содержание в нем остаточных гемицеллюлоз составляет 2,8-3,1 \% мас. (табл. 2). Как следует из приведенных в табл. 2 данных, наибольшим изменениям в процессе гидролиза подвергаются гемицеллюлозы. Учитывая то, что в исходной древесине березы их содержание составляет 27,3 \% мас., уже после 5 ч гидролиза 1-4 \% $\mathrm{H}_{2} \mathrm{SO}_{4}$ в лигноцеллюлозном продукте остается 5,5-2,8 \% мас. гемицеллюлоз. Причем с увеличением продолжительности гидролиза содержание гемицеллюлоз уменьшается независимо от концентрации сернокислотного катализатора.

$$
-215-
$$


Таблица 1. Влияние концентрации сернокислотного катализатора и продолжительности гидролиза древесины березы на ее конверсию и содержание гемицеллюлоз в лигноцеллюлозном продукте (температура $100{ }^{\circ} \mathrm{C}$, гидромодуль 8 )

\begin{tabular}{|c|c|c|c|c|c|c|c|c|c|c|}
\hline \multirow[b]{3}{*}{$\begin{array}{c}\text { Концентрация } \\
\text { катализатора }\end{array}$} & \multicolumn{10}{|c|}{ Продолжительность гидролиза, ч } \\
\hline & \multicolumn{2}{|c|}{1} & \multicolumn{2}{|c|}{2} & \multicolumn{2}{|c|}{3} & \multicolumn{2}{|c|}{4} & \multicolumn{2}{|c|}{5} \\
\hline & 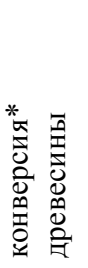 & 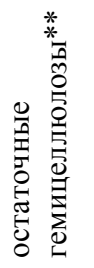 & 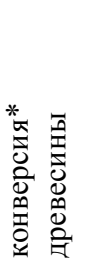 & 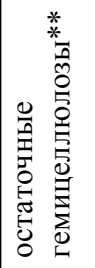 & 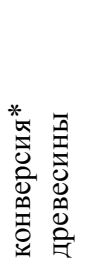 & 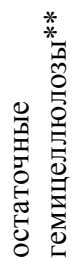 & 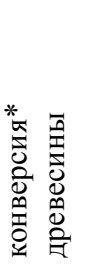 & 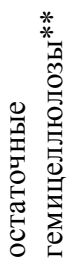 & 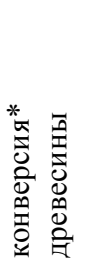 & 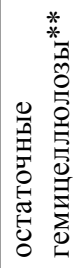 \\
\hline $1 \% \mathrm{H}_{2} \mathrm{SO}_{4}$ & 9,3 & 17,3 & 14,1 & 12,7 & 16,2 & 7,3 & 22,6 & 6,4 & 29,3 & 5,5 \\
\hline $2 \% \mathrm{H}_{2} \mathrm{SO}_{4}$ & 15,9 & 12,2 & 18,3 & 8,6 & 22,8 & 4,8 & 29,1 & 3,8 & 33,3 & 4,2 \\
\hline $3 \% \mathrm{H}_{2} \mathrm{SO}_{4}$ & 16,4 & 10,0 & 21,2 & 6,3 & 22,5 & 5,2 & 32,3 & 4,5 & 35,1 & 3,1 \\
\hline $4 \% \mathrm{H}_{2} \mathrm{SO}_{4}$ & 22,3 & 7,9 & 27,4 & 5,1 & 26,2 & 3,4 & 28,6 & 3,2 & 36,9 & 2,8 \\
\hline
\end{tabular}

*Конверсия, \% от массы воздушно-сухой древесины, ** \% от массы воздушно-сухого лигноцеллюлозного продукта.

Целлюлоза в процессе кислотного гидролиза при температуре $100{ }^{\circ} \mathrm{C}$ подвергается конверсии в меньшей степени, чем гемицеллюлозы. Содержание целлюлозы в лигноцеллюлозном продукте не уменьшается с увеличением продолжительности гидролиза, а, наоборот, увеличивается до 70,2-70,4 \% мас. Рост содержания целлюлозы в продукте связан с преимущественным удалением гемицеллюлоз в процессе гидролиза.

Некоторое увеличение содержания лигнина в лигноцеллюлозе по сравнению с исходной древесиной березы, очевидно, связано с тем, что в процессе гидролиза древесины происходит образование лигноподобных веществ (так называемого псевдолигнина) [18].

Выход целевого продукта гидролиза древесины березы - ксилозы - зависит от концентрации сернокислотного катализатора и продолжительности процесса. Максимальные выходы ксилозы (72,4-77,1 \% мас. от исходного содержания гемицеллюлоз) получены гидролизом древесины березы в течение 5 ч с использованием 2 и $3 \% \mathrm{H}_{2} \mathrm{SO}_{4}$ соответственно (рис. 1). Повышенная концентрация катализатора $\left(4 \% \mathrm{H}_{2} \mathrm{SO}_{4}\right)$ при продолжительности гидролиза более 2 ч не позволяет получить ксилозу с высоким выходом, который не превышает 58-59 \% мас. Увеличение продолжительности гидролиза до 5 ч снижает выход ксилозы до 48 \% мас. Уменьшение концентрации ксилозы обусловлено реакциями ее вторичных превращений. Образующиеся моносахариды подвергаются многоступенчатым превращениям, которые приводят к снижению выхода сахаров и образованию фурановых производных и других ингибиторов биохимических процессов [19].

По данным РФА (рис. 2), гидролиз древесины березы в разбавленных растворах серной кислоты приводит к увеличению интенсивности и уменьшению ширины пиков с индексом 002. Ширина рентгеновских дифракционных линий зависит от размеров областей кристалличности (областей когерентного рассеяния): чем больше размер этих областей, тем меньше ширина пика на рентгенограмме. Хорошо окристаллизованный и однородный по параметрам решетки материал дает узкие и высокие дифракционные пики (линии 2 и 3 на рис. 3). Характерные пики 
Таблица 2. Влияние концентрации сернокислотного катализатора на состав лигноцеллюлозного продукта гидролиза древесины березы при температуре $100{ }^{\circ} \mathrm{C}$ и гидромодуле 8

\begin{tabular}{|c|c|c|c|c|}
\hline \multirow[t]{2}{*}{ Сырье } & \multirow{2}{*}{$\begin{array}{c}\text { Продолжительность } \\
\text { гидролиза, ч }\end{array}$} & \multicolumn{3}{|c|}{$\begin{array}{c}\text { Содержание основных компонентов } \\
\text { в лигноцеллюлозном продукте, \% мас. }\end{array}$} \\
\hline & & гемицеллюлозы & целлюлоза & лигнин \\
\hline $\begin{array}{l}\text { Исходная } \\
\text { древесина березы * }\end{array}$ & Отсутствует & 27,3 & 46,8 & 21,7 \\
\hline \multirow{5}{*}{$\begin{array}{l}\text { Древесина после } \\
\text { гидролиза } \\
1 \% \mathrm{H}_{2} \mathrm{SO}_{4}^{* *}\end{array}$} & 1 & 17,3 & 56,8 & 20,2 \\
\hline & 2 & 12,7 & 61,4 & 20,8 \\
\hline & 3 & 7,3 & 64,8 & 22,0 \\
\hline & 4 & 6,4 & 65,7 & 22,5 \\
\hline & 5 & 5,5 & 67,0 & 23,7 \\
\hline \multirow{5}{*}{$\begin{array}{l}\text { Древесина после } \\
\text { гидролиза } \\
2 \% \mathrm{H}_{2} \mathrm{SO}_{4} * *\end{array}$} & 1 & 12,2 & 59,9 & 19,8 \\
\hline & 2 & 8,6 & 63,5 & 21,0 \\
\hline & 3 & 4,8 & 67,3 & 23,4 \\
\hline & 4 & 3,8 & 68,3 & 23,6 \\
\hline & 5 & 4,2 & 68,8 & 25,0 \\
\hline \multirow{5}{*}{$\begin{array}{l}\text { Древесина после } \\
\text { гидролиза } \\
3 \% \mathrm{H}_{2} \mathrm{SO}_{4} * *\end{array}$} & 1 & 10,0 & 63,2 & 21,3 \\
\hline & 2 & 6,3 & 65,8 & 23,0 \\
\hline & 3 & 5,2 & 66,9 & 25,2 \\
\hline & 4 & 4,5 & 67,8 & 26,0 \\
\hline & 5 & 3,1 & 69,0 & 27,1 \\
\hline \multirow{5}{*}{$\begin{array}{l}\text { Древесина после } \\
\text { гидролиза } \\
4 \% \mathrm{H}_{2} \mathrm{SO}_{4} * *\end{array}$} & 1 & 7,9 & 64,2 & 22,3 \\
\hline & 2 & 5,1 & 67,0 & 25,7 \\
\hline & 3 & 3,4 & 68,9 & 27,6 \\
\hline & 4 & 3,2 & 70,2 & 28,4 \\
\hline & 5 & 2,8 & 70,4 & 28,8 \\
\hline
\end{tabular}

*_-От массы воздушно-сухой древесины; **- от массы воздушно-сухого лигноцеллюлозного продукта.

в области $2 \theta=15-16^{\circ}$ обусловлены с дифракцией рентгеновских лучей от плоскостей 101 и $10 \overline{1}$ кристаллической решетки. Интенсивность рефлекса в области $2 \theta=22,5^{\circ}$ соответствует плоскости 002 кристаллической решетки природной целлюлозы I [20, 21]. Таким образом, в результате предварительного гидролиза исходной древесины березы в растворах с содержанием серной кислоты 3 \% мас. произошло удаление легкогидролизуемых полисахаридов нерегулярного строения. Оставшаяся упорядоченная часть надмолекулярной структуры твердого остатка гидролизованной древесины соответствует кристаллической решетке целлюлозы I.

Рассчитанный из дифрактограмм индекс кристалличности исходной древесины березы равен 0,49 , а для образцов, гидролизованных $3 \%$ мас. $\mathrm{H}_{2} \mathrm{SO}_{4}$, при температуре $100{ }^{\circ} \mathrm{C}$ в течение 2 и 5 ч, - соответственно 0,59 и 0,63 .

Твердый остаток гидролиза древесины березы растворами серной кислоты содержит целлюлозу, лигнин и остатки трудноизвлекаемых гемицеллюлоз.

Анализ гидролизатов древесины березы методом газовой хроматографии показал присутствие в растворах не только целевого продукта - ксилозы, но и в незначительных количествах 


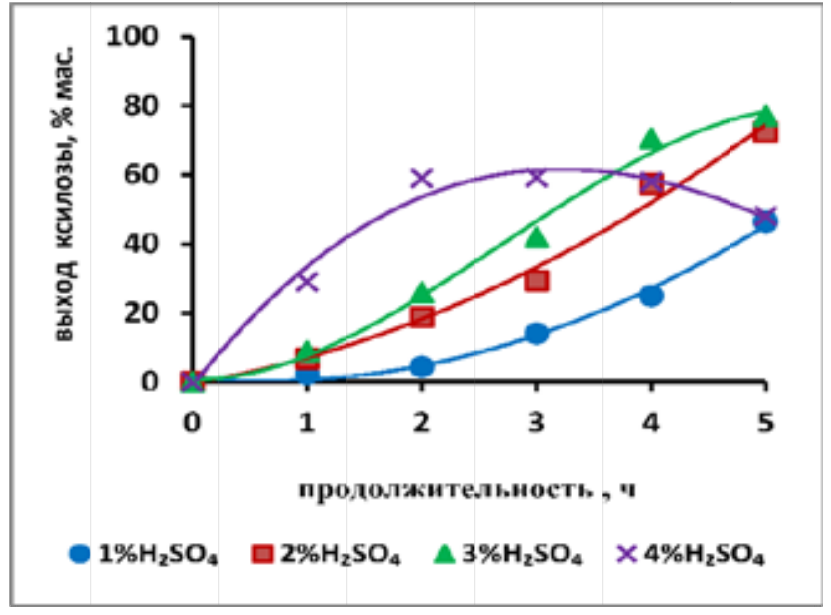

Рис. 1. Влияние концентрации сернокислотного катализатора и продолжительности гидролиза древесины березы на выход ксилозы (температура $100{ }^{\circ} \mathrm{C}$, гидромодуль 8)

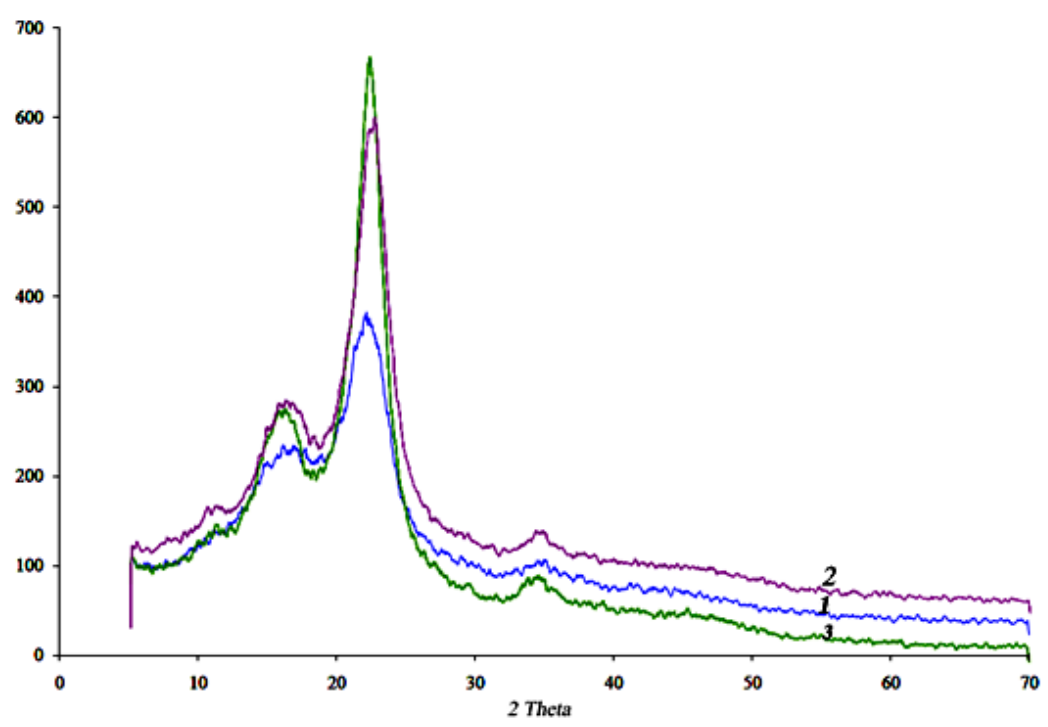

Рис. 2. Дифрактограммы исходной древесины березы (1), после гидролиза $3 \% \mathrm{H}_{2} \mathrm{SO}_{4}$ в течение 2 ч (2), после гидролиза $3 \% \mathrm{H}_{2} \mathrm{SO}_{4}$ в течение 5 ч (3)

маннозы, глюкозы. Манноза и глюкоза являются продуктами гидролиза гемицеллюлоз и легкогидролизуемой части целлюлозы, причем манноза может образовываться в результате каталитической эпимеризации глюкозы. Типичные хроматограммы гидролизатов из древесины березы представлены на рис. 3. Хроматограммы включают пики всех содержащихся в пробе гидролизата таутомеров моносахаров.

Известно [22], что основными компонентами гидролизатов, образующимися при гидролизе гемицеллюлоз, являются моносахара, а также происходит образование растворимых олигомерных продуктов, основным из которых является ксилобиоза. В составе растворенных про- 


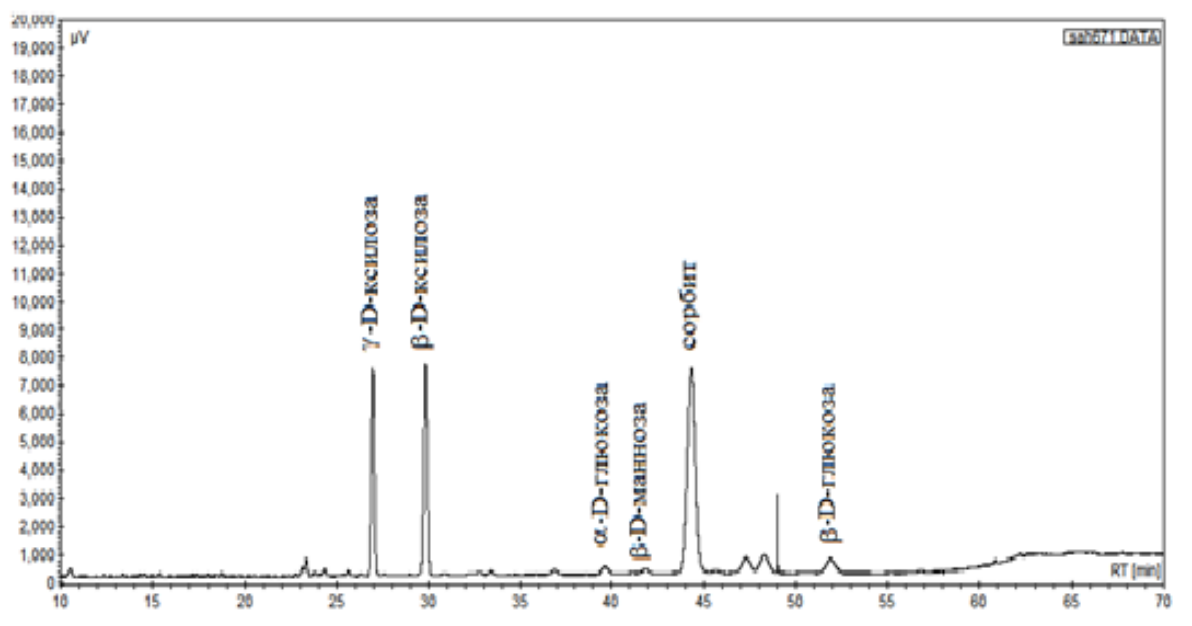

A

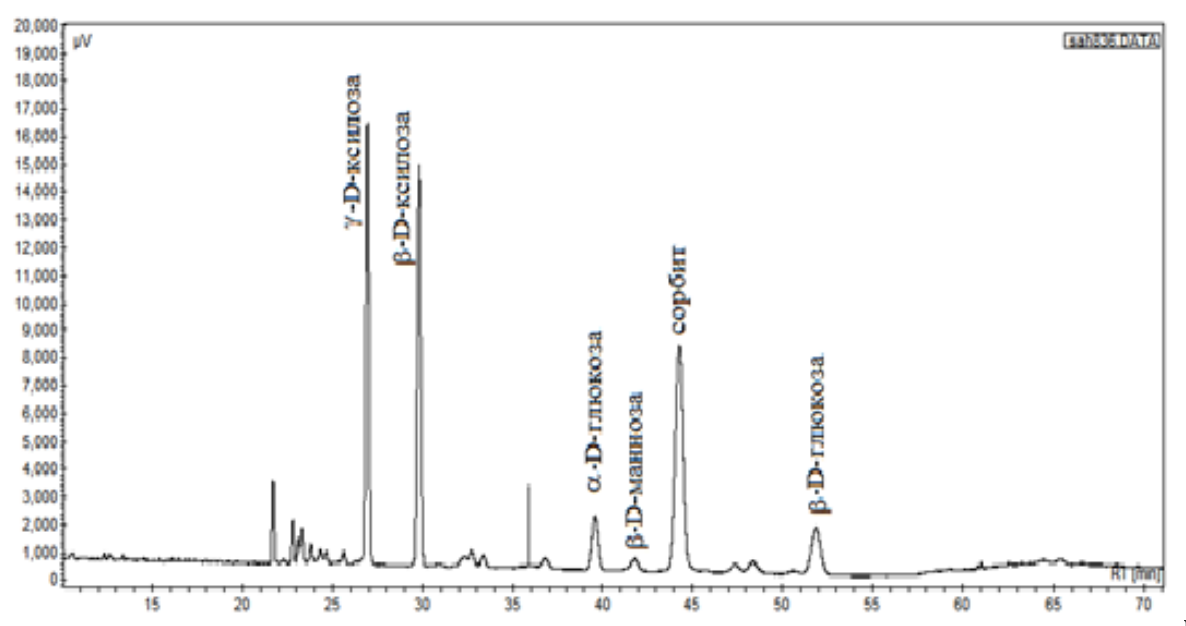

Рис. 3. Хроматограмма гидролизатов, полученных гидролизом древесины березы $3 \% \mathrm{H}_{2} \mathrm{SO}_{4}$ при $100{ }^{\circ} \mathrm{C}$ в течение 2 ч (А) и 5 ч (Б)

дуктов определены следующие моносахара: ксилоза (2,3-77,1 \% мас.), манноза (0,12-3,6 \% мас.) и глюкоза (0,9-12,7 \% мас.).

\section{Заключение}

Изучен процесс гидролиза древесины березы разбавленной серной кислотой при температуре $100{ }^{\circ} \mathrm{C}$ и атмосферном давлении. Установлено, что максимальный выход ксилозы $(72,4$ и 77,1 \% мас. от исходного содержания гемицеллюлоз) получен гидролизом древесины в течение 5 ч соответственно 2 и $3 \% \mathrm{H}_{2} \mathrm{SO}_{4}$. Газохроматографический анализ полученных гидролизатов показал, что их основным продуктом является ксилоза, а также в незначительных количествах присутствуют манноза и глюкоза.

Твердый остаток гидролиза древесины березы разбавленной серной кислотой содержит целлюлозу (56,8-70,4 \% мас.), лигнин (19,8-28,8 \% мас.) и остаточные гемицеллюлозы (2,8-15,3 \% 
мас.). По данным РФА, индексы кристалличности гидролизованной древесины березы выше, чем у исходной, и составляют $0,59-0,63$.

Работа выполнена при финансовой поддержке Министерства образования и науки Российской Федерации (проект RFMЕFI60714X0031).

\section{Список литературы}

1. Lee Hong-Joo, Lim Woo-Seok, Lee Jae-Won Improvement of ethanol fermentation from lignocellulosic hydrolysates by the removal of inhibitors // Journal of Industrial and Engineering Chemistry. 2013. Vol. 19. P. 2010-2015.

2. Chemin M., Wirotius A-L., Ham-Pichavant F. et al. Well-defined oligosaccharides by mild acidic hydrolysis of hemicelluloses // European Polymer Journal. 2015. V. 66. P. 190-197.

3. R. Wang, R. Koppram, L. Olsson. Kinetic modeling of multi-feed simultaneous saccharification and co-fermentation of pretreated birch to ethanol // Bioresource Technology. 2014. 172. P. 303-311.

4. Zheng, Y., Pan Z., Zhang R. Overview of biomass pretreatment for cellulosic ethanol production // International Journal of Agricultural and Biological Engineering. 2009. №3. P. 51-68.

5. Кузнецов Б.Н., Кузнецова С.А., Данилов В.Г. и др. Получение химических продуктов из древесины березы методами каталитического окисления и кислотного катализа // Химия в интересах устойчивого развития. 2005. №13. С. 531-539. [Kuznetsov B.N., Kuznetsova S.A., Danilov V.G. at el. Obtaining of chemicals from wood of a birch by methods of catalytic oxidation and acid catalysis. Chemistry for Sustainable Development. 2005. №13. P. 531-539. (In Russ.)]

6. Samar K. Bose, Vincent A. Barber, Ericka F. Alves. An improved method for the hydrolysis of hardwood carbohydrates to monomers // Carbohydrate Polymers. 2009. Vol. 78. P. 396-401.

7. Borrega M., Nieminen K., Sixta H. Degradation kinetics of the main carbohydrates in birch wood during hot water extraction in a batch reactor at elevated temperatures // Bioresource Technology. 2011 Vol. 102. P. 10724-10732.

8. Kallionen A., Hakola M., Riekkola T. et al. A novel alkaline oxidation pretreatment for spruce, birch and sugar cane bagasse // Bioresource Technology. 2013. Vol. 140. P. 414-420.

9. Кузнецов Б.Н., Шарыпов В.И., Кузнецова С.А. и др. Влияние активирующих воздействий на состав, строение и реакционную способность древесины осины // Химия в интересах устойчивого развития. 2012. №5. С. 559-565. [Kuznetsov B.N., Sharypov V.I., Kuznetsova S.A. at el. Effect of Different Activation Methods on the Composition, Structure and Reactivity of Aspen Wood. Chemistry for Sustainable Development. 2012. №5. P. 559-565. (In Russ.)]

10. Westbye P., Köhnke T., Gatenholm P. Fractionation and characterization of xylan rich extracts from birch // Holzforschung. 2008. V. 62. P. 31-37.

11. Alonso D. M., Bong J. Q., Dumesic J. A. Catalytic conversion of biomass to biofuels // Green Chemistry. 2010. V. 12. P. 1493-1513.

12. Wyman, C.E. Biomass ethanol: Technical progress, opportunities, and commercial challenges // Annu. Rev. Energy Environ. 1999. V. 24. P. 189.

13. Eta V., Anugwom I., Virtanen P.. Loop vs. batch reactor setups in the fractionation of birch chips using switchable ionic liquids // Chemical Engineering Journal. 2014. V. 238. P. 242-248. 
14. Кузнецов Б.Н., Чесноков Н.В., Гарынцева Н.В., Яценкова О.В. Интегрированная каталитическая переработка древесины осины в жидкие и твердые биотоплива // Journal of Siberian Federal University. Chemistry. 2013. T. 6 № 3. P. 286-298. [B. N. Kuznetsov, N. V. Chesnokov, N. V. Garyntseva, O. V. Yatsenkova. Integrated Catalytic Processing of Aspen Wood into Liquid and Solid Biofuels. Journal of Siberian Federal University. Chemistry. 2013. T. 6 № 3. P. 286-298.]

15. Оболенская А.В., Ельницкая 3.П., Леонович А.А. Лабораторные работы по химии древесины и целлюлозы. М.: Экология, 1991. 321 с. [Obolenskaya A.B., El'nitskaya Z.P., Leonovich A.A. Laboratory work on the chemistry of wood and cellulose, Moscow, 1991. 321 P. (In Russ.)]

16. Ruiz-Matute A.I., Hernandez-Hernandez O., Rodriguez-Sanchez S., Sanz M.L., Martinez-

Castro I. Derivatization of carbohydrates for GC and GC-MS analyses // J. Chromatogr. B. 2011. V. 879. P. 1226-1240.

17. Park S., Baker J.O., Himmer M. E. at el. Cellulose crystallinity index: measurement techniques and their impact on interpreting cellulose performance // Biothechnology for fuels. 2010. V. 3. P. $10-20$.

18. Кузнецова С.А., Александрова Н.Б., Кузнецов Б.Н. Состав и превращения основных компонентов автогидролизованной древесины сосны, ели и осины // Химия в интересах устойчивого развития. 2001. 9. № 5. С. 655-665. [Kuznetsova S.A., Alexandrova N.B., Kuznetsov B.N. Composition and transformation of the main components of autohydrolyzed pine, spruce and aspen // Chemistry for sustainable development. 2001. T. 9. № 5. P. 655-665.(in Russ.)]

19. Gírio FM, Fonseca C, Carvalheiro F, Duarte LC, Marques S, Bogel-lukasik R. Hemicelluloses for fuel ethanol: a review // Biores Technol. 2010. Vol. 101. P. 4775-4800.

20. Hult L. E., Iversen T., Sugiyama J. Characterization of the supramolecular structure of cellulose in wood pulp fibres // Cellulose. 2003. 10. P. 103-110.

21. Garvey C.J., Parker I.H., Simon G.P. On the interpretation of X-ray diffraction powder patterns in terms of the nanostructure of cellulose I fibres // Macromol Chem Phys. 2005. 206. P. 1568-1575.

22. P. Dhepe, R. Sahu. A solid-acid-based process for the conversion of hemicelluloses // Green Chem. 2010. 12. P. 2153-2156. 